\title{
Análise comparativa das alterações nos fluxos de tensão do joelho nas próteses totais e unicompartimentais cimentadas Estudo experimental em dez cadáveres humanos
}

\author{
comparative analisys of changes in knee strain transfer flow in total and \\ unicompartmental cemented prostheses. \\ A trial in ten human cadavers
}

\author{
J osé Ricardo Pécora ${ }^{1}$, Márcia Uchoa de Rezende², Arnaldo J osé Hernandez ${ }^{3}$, \\ Marco Martins Amatuzzi ${ }^{4}$, César Augusto Martins Pereira ${ }^{5}$, Tomaz Puga Leivas ${ }^{6}$
}

\section{RESUMO}

Análise comparativa das alterações nos fluxos de tensão do joelho nas próteses totais e unicompartimentais cimentadas. Estudo experimental em dez cadáveres humanos.

Os autores comparam as alterações nos fluxos de tensão do fêmur distal e da tíbia proximal provocadas pelas próteses total e unicompartimental cimentadas do joelho, por meio de extensometria elétrica em 10 cadáveres humanos. Utilizam um dispositivo mecânico para adaptação das peças anatômicas à máquina de ensaios mecânicos Kratos 5002. Concluem: 1) A prótese total do joelho mantém o padrão de distribuição das cargas no terço distal do fêmur; 2) A prótese unicompartimental aumenta as tensões de compressão na cortical medial e as tensões de tração na cortical lateral do terço distal do fêmur; 3) Os componentes tibiais (parcial medial e total) aumentam, da mesma forma, as tensões de compressão na cortical póstero-medial da tíbia.

Descritores: Artroplastia do J oelho; Prótese do joelho; Fêmur.

\section{INTRODUÇÃO}

A função do joelho pode ser gravemente afetada por processos inflamatórios ou degenerativos. 0 número de pacientes que procuram tratamento médico devido ao comprometimento da capacidade funcional dos joelhos, particularmente com artrose, tem crescido significativamente, tanto pelo aumento da long evidade da população, quanto pelo aumento da atividade dos indivíduos nesta faixa etária mais avançada.

Trabalho realizado no Instituto de Ortopedia e Traumatologia do Hospital das Clínicas da Faculdade de Medicina da Universidade de São Paulo.

1 - Mestre e Doutor em Ortopedia e Traumatologia. Médico Assistente do Grupo de J oelho.

2 - Mestre e Doutor em Ortopedia e Traumatologia. Médica Assistente do Grupo de J oelho.

3 - Mestre e Doutor em Ortopedia e Traumatologia pela. Médico Chefe do Grupo de Joelho

4 - Chefe do Departamento

5 - Tecnólogo em Saúde. Coordenador da Área de Bioengenharia do Laboratório de Biomecânica LIM-41.

6 - Coordenador da Comissão de Projetos do Conselho Diretor.

Endereço para correspondência: Rua Dr. Ovídio Pires de Campos, 333 - 30 andar CEP 05403-010 - São Paulo - SP

Trabalho recebido em 21/08/2002. Aprovado em 20/03/2003

\section{SUMMARY}

Load transfer changes on cemented total and unicompartmental knee prosthesis. Experimental study on ten human cadavers.

The authors compare the load transfer changes on the distal femur and proximal tibia due to cemented total and unicompartmental knee prosthesis under compressive load-bearing on ten human cadavers employing strain gauges and a Kratos 5002 stress-testing system. The conclusions were: 1) The Total knee prosthesis does not alter the load transfer on the distal femur; 2 ) The unicompartmental knee prosthesis increases the compression load on the femoral medial cortex and increases the strain tension loads on the femoral lateral cortex; 3 ) The tibial components (partial medial and total) increase the compression strain tension on the postero-medial cortex of the tibia.

Key words: Arthroplasty; Replacement; knee; knee Prosthesis; femur.

\section{INTRODUCTION}

Inflammatory or degenerative processes can severely affect the knee function. The number of patients seeking medical care due to functional impairment of the knee ability, particularly those with arthrosis, has increased signific antly, both due to the increase of longevity of the population and the increase of the activities of individuals in this older age group.

Arthroplasties have been an important weapon in the reco-

This study was performed in the Institute of Orthopedics and Traumatology, Hospital das Clinicas, Faculty of Medicine, University of Sao Paulo, Sao Paulo, SP, Brazil.

1 - Master and PHD Degrees in Orthopedics and Traumatology. Physician Assistant of the Knee Group.

2 - Master and PHD Degrees in Orthopedics and Traumatology. Physician Assistant of the Knee Group.

3 - Master and PHD Degrees in Orthopedics and Traumatology. Head Physician of the Knee Group

4 - Head of Department

5 - Health Technologist. Coordinator of the Bioengineering Area, LIM-41

Biomechanics Laboratory.

6 - Coordinator of the Projects Committee, Board of Directors.

Mail adress: Rua Dr. Ovídio Pires de Campos, 333 - 3 andar CEP 05403-010 - São Paulo - SP 
As artroplastias têm sido uma arma importante na recuperação da função dos joelhos desses pacientes quando existe indicação de tratamento cirúrgico. Elas podem ser divididas, de acordo com os componentes articulares a serem substituídos, em dois tipos: a artroplastia total, em que são substituídos todos os três compartimentos articulares (femorotibial medial, femorotibial lateral e o femoropatelar) e a artroplastia unicompartimental em que apenas um dos compartimentos, seja o femorotibial medial ou lateral é substituído.

A vida útil das artroplastias do joelho tem aumentado ao longo do tempo devido à melhora dos instrumentais cirúrgicos, ao aprimoramento da técnica cirúrgica e, principalmente, ao aumento do conhecimento da biomecânica do joelho, contribuindo para a evolução dos desenhos dos componentes protéticos.

Porém, fatores biológicos e mecânicos ainda comprometem a vida útil das artroplastias. Dentre os fatores biológicos estão a infecção, reação de corpo estranho aos componentes do implante, e o comprometimento das suas estruturas de sustentação, sejam as estruturas capsuloligamentares ou a própria estrutura óssea. Quanto aos fatores mecânicos podemos citar os micromovimentos que ocorrem na interface entre o osso e o material protético e as alterações das tensões no fêmur e na tíbia devido à instalação das próteses.

As alterações das tensões de uma estrutura podem ser avaliadas através das microdeformações superficiais observadas quando esta estrutura é submetida a uma determinada carga ou força externa, em regime elástico.

O objetivo deste trabalho é comparar as alterações nos fluxos de tensão do joelho, provocadas pelas próteses totais e unicompartimentais, quando submetido a carga axial, avaliando-se as microdeformações superficiais no terço distal do fêmur e no terço proximal da tíbia.

\section{CASUÍSTICA E MÉTODO}

Dez pares de joelhos humanos foram retirados de cadáveres adultos, do sexo masculino, com idade variando de 25 a 83 anos e média de idade de 52,2anos. Avaliou-se a possibilidade de alterações prévias nas peças anatômicas que pudessem interferir nos resultados.

As peças foram retirados por meio de osteotomia do fêmur, tíbia e fíbula, com serra manual, a dezoito centímetros da linha articular femorotibial.

Removeu-se as estruturas musculotendíneas e vasculonervosas e todo o periósteo, preservando-se a cápsula articular, os ligamentos colaterais e cruzados, assim como 0 aparelho extensor do joelho (ligamento patelar, patela e o tendão quadricipital).

Foram determinados nove pontos para avaliar a deformação superficial, sendo cinco no fêmur (números 1 a 5) e quatro na tíbia (números 6 a 9) em cada joelho.

No fêmur, padronizou-se a altura do polo superior da patela, com o joelho em extensão como ponto de referência, para localizar os pontos de medida da deformação superficial 1,2 e 3 . very of the knee function for these patients when surgical treatment is indicated. According to the joint components to be replaced, arthroplasties can be divided into two types: total arthroplasty, where all three joint compartments (femorotibial medial, femorotibial lateral and femoropatellar) are replaced; and unicompartmental arthroplasty, where only one of the compartments, either the medial or lateral femorotibial, is replaced.

The useful life of knee arthroplasties has increased along the time due to improvements introduced in surgical instruments and the sophistication of the surgical technique, but mainly due to the increasing knowledge on knee biomechanics, which contributes to the evolution in the design of prosthetic components.

However, biological and mechanical factors still impair the useful life of arthroplasties. Biological factors include infection, response of foreign matter to the components of the implant, and the impairment of their supporting structures, meaning both the capsuloligamentar structures and the bone structure itself As to mechanical factors, we may mention the micro motions occurring in the interface between the bone and the prosthetic material and the strain changes in the femur and tibia, due to the placement of the prostheses.

The strain changes in a structure may be evaluated by means of the surface microdeformations seen when the structure is subject to a given load or external force under elastic conditions.

The purpose of this trial is to compare the changes in the knee strain flows promoted by total and unicompartmental prostheses, when subjected to an axial load, and evaluate the surface microdeformations in the distal third of the femur and in the proximal third of the tibia.

\section{CASES AND METHOD}

Ten pairs of human knees were removed from adult male cadavers between 25 and 83 years, with a mean of 52.2 years. The possibility of previous changes in the anatomical pieces capable of interfering in the results was evaluated.

The pieces were removed by femoral, tibial and fibular osteostomy using a handsaw, at a distance of eighteen centimeters from the femorotibial joint line.

The musculotendinous and vasculonervous structures and the entire periosteum were removed, although the joint capsule, and the collateral and crossed ligaments were preserved, as well as the knee extensor apparatus (patellar ligament, patella, and quadriccipital tendon).

In order to evaluate the surface deformation, nine points were determined, five of them in the femur (numbered from 1 to 5 ) and four in the tibia (numbered from 6 to 9 ) in each knee.

To locate the measuring points of the surface deformation (points 1,2 and 3), the height of the upper pole of the patella, with the knee extended, was standardized in the femur as a reference point.

Point 1 : Medial femur: Middle point of the anteroposterior projection of the femur at its medial side, at the level of the upper pole of the patella (Figure 1). 
Ponto 1 : Fêmur medial: Ponto médio da projeção anteroposterior do fêmur na sua face medial, na altura do polo superior da patela. (Figura 1).

Ponto 2 : Fêmur posterior: Ponto médio da projeção lateromedial do fêmur na sua face posterior, na altura do polo superior da patela. (Figura 2).

Ponto 3 : Fêmur lateral: Ponto médio da projeção anteroposterior do fêmur na sua face lateral, na altura do polo superior da patela. (Figura 3).

Os pontos 4 e 5 foram marcados proximalmente ao polo superior da patela, numa distância igual ao diâmetro anteroposterior do fêmur medido na linha dos pontos 1,2 e 3 .

Ponto 4 : Fêmur anterolateral: Ponto médio lateral da projeção lateromedial do fêmur na sua face anterior na altura do polo superior da patela acrescido do maior diâmetro anteroposterior do fêmur. (Figura 4).

Ponto 5 : Fêmur anteromedial: Ponto médio medial da projeção lateromedial do fêmur na sua face anterior na altura do polo superior da patela acrescido do maior diâmetro anteroposterior do fêmur. (Figura 4).

Na tíbia proximal, padronizou-se a altura da porção distal da sindesmose tibiofibular proximal, como ponto de referência para localizar a altura dos pontos de medida da deformação superficial 6, 7, 8 e 9.

Ponto 6 : Tíbia anteromedial: Ponto médio da superfície anteromedial da tíbia na altura da porção distal da sindesmose tibiofibular proximal. (Figura 5).

Ponto 7 : Tíbia posteromedial: Ponto do terço medial da superfície posterior da tíbia na altura da porção distal da sindesmose tibiofibular proximal. (Figura 6).

Ponto 8 : Tíbia posterolateral: Ponto do terço lateral da superfície posterior da tíbia na altura da porção distal da sindesmose tibiofibular proximal. (Figura 6).
Point 2 : Posterior femur: Middle point of the lateromedial projection of the femur in its posterior side, at the level of the upper pole of the patella (Figure 2).

Point 3 : Lateral femur: Middle point of the anteroposterior projection of the femur in its lateral side, at the level of the upper pole of the patella (Figure 3).

Points 4 and 5 were marked proximally to the upper pole of the patella, at a distance equal to the anteroposterior diameter of the femur, measured on the line of points 1,2 and 3 .

Point 4 : Anterolateral femur: Lateral middle point of the lateromedial projection of the femur in its anterior side at the level of the upper pole of the patella plus the largest anteroposterior diameter of the femur (Figure 4).

Point 5 : Anteromedial femur: Medial middle point of the lateromedial projection of the femur in its anterior side at the level of the upper pole of the patella plus the largest anteroposterior diameter of the femur (Figure 4).

In the proximal tibia, the height of the distal portion of the proximal tibiofibular syndesmosis was standardized as a reference point to locate the height of measuring points $6,7,8$ and 9 of the surface deformation.

Point 6 : Anteromedial tibia: Middle point of the tibial anteromedial surface at the level of the distal portion of the proximal tibiofibular syndesmosis (Figure 5).

Point 7 : Posteromedial tibia: Point in the medial third of the tibial posterior surface at the level of the distal portion of the proximal tibiofibular syndesmosis (Figure 6).

Point 8 : Posterolateral tibia: Point in the lateral third of the tibial posterior surface at the level of the distal portion of the proximal tibiofibular syndesmosis (Figure 6).

Point 9 : Anterolateral tibia: Middle point of the tibial anterolateral surface at the level of the distal portion of the proximal tibiofibular syndesmosis (Figure 5).

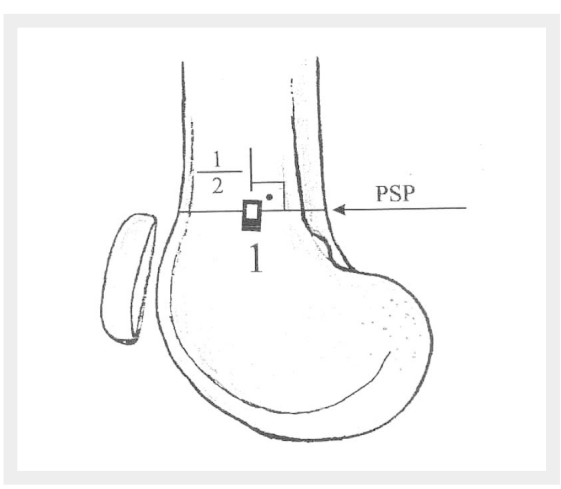

FIGURA 1: Esquema representativo da localização do ponto 1 (fêmur medial) onde PSP corresponde à linha que tangencia 0 polo superior da patela, perpendicularmente ao eixo anatômico do fêmur.

FIGURE 1: Representation of the location of Point 1 (medial femur) where PSP

corresponds to the tangent to the upper pole of the patella, perpendicularly to the anatomical axis of the femur.

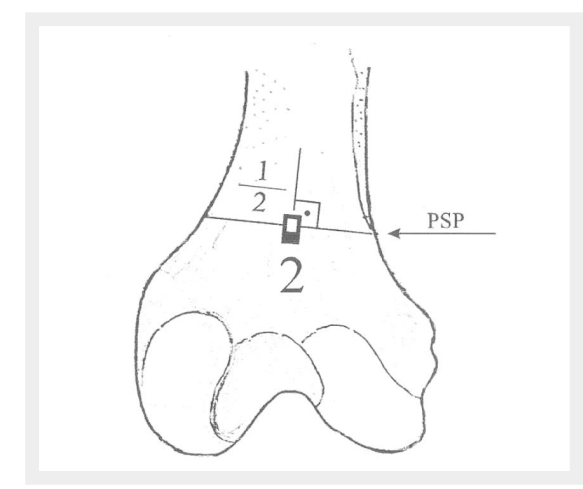

FIGURA 2: Esquema representativo da localização do ponto 2 (fêmur posterior) onde PSP corresponde à linha que tangencia o polo superior da patela perpendicularmente ao eixo anatômico do fêmur.

FIGURE 2: Representation of the location of Point 2 (posterior femur) where PSP corresponds to the tangent to the upper pole of the patella perpendicularly to the anatomical axis of the femur.

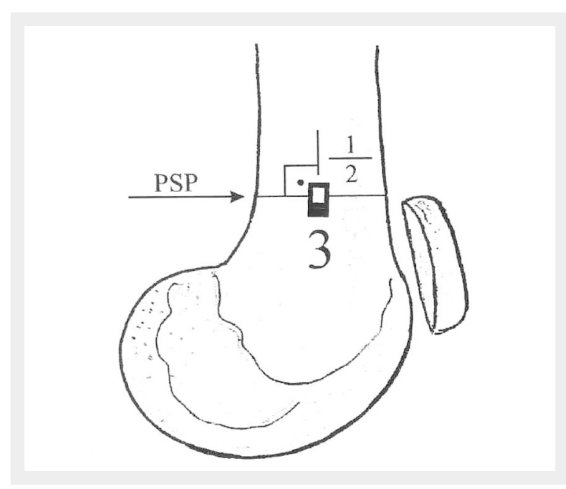

FIGURA 3: Esquema representativo da localização do ponto 3 (fêmur lateral), onde PSP corresponde à linha que tangencia 0 polo superior da patela, perpendicularmente ao eixo anatômico do fêmur.

FIGURE 3: Representation of the location of Point 3 (lateral femur), where PSP

corresponds to the tangent to the upper pole of the patella, perpendicularly to the anatomical axis of the femur. 
Ponto 9 : Tíbia anterolateral: Ponto médio da superfície anterolateral da tíbia na altura da porção distal da sindesmose tibiofibular proximal. (Figura 5).

Para realizar a análise das tensões sob compressão, foi desenvolvido um dispositivo mecânico composto de dois cilindros (um superior para o fêmur e um inferior para a tíbia e fíbula) que permitia posicionar o joelho em extensão. As extremidades ósseas foram fixadas aos respectivos cilindros com cimento acrílico autopolimerizante odontológico J et Clássico ${ }^{\circledR}$ (polimetilmetacrilato).

Extensômetros Elétricos Kratos, modelo: PA-06-062 AH-350L., foram fixados ao osso nos pontos predeterminados (1 a 9), com adesivo de cianoacrilato Super-Bonder-Loctite ${ }^{\circledR}$ e posteriormente revestidos por resina de poliuretano. (Figura 7).

Após a instalação dos extensômetros, o conjunto formado pela peça anatômica e o dispositivo mecânico de fixação foi colocado à máquina de ensaios mecânicos Kratos 5002 (Figura 8). Cada extensômetro foi conectado à ponte de extensometria P3500, fabricado pela Measurement Group ${ }^{\circledR}$, por meio de cabo com três fios multifilamentares com $0,5 \mathrm{~mm}$ de diâmetro, segundo especificação do fabricante, para a leitura das microdeformações superficiais.

A carga foi aplicada no sentido craneocaudal (compressão) com velocidade de $5 \mathrm{~mm}$ por minuto até atingir o valor de 686,70 $\mathrm{N}$ (70 kgf) e aguardou-se cerca de vinte minutos devido ao escoamento do tecido ósseo (efeito viscoelástico), até a carga estabilizar-se em 343,35 N (35 kgf). Uma vez estabilizada a carga, efetuou-se a leitura das microdeformações dos nove extensômetros. Retirou-se a carga e, após trinta minutos repetiu-se o ensaio. Anotou-se os resultados e calculou-se a média dos dois resultados numéricos de cada extensômetro nos dois testes.

Após a realização dos testes com os joelhos íntegros, retirou-se todo o aparelho extensor do joelho e colocou-se no compartimento medial do

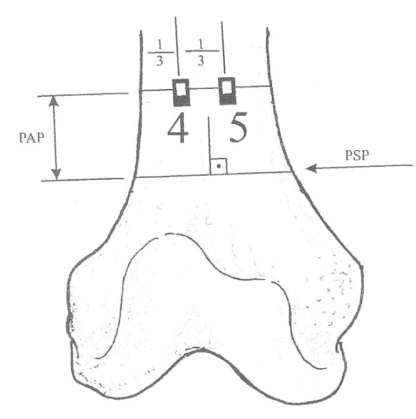

FIGURA 4: Esquema representativo da localização do ponto 4 (fêmur anterolateral) e do ponto 5 (fêmur anteromedial), onde PSP corresponde à linha que tangencia o polo

superior da patela, perpendicularmente ao eixo anatômico do fêmur e PAP corresponde à

projeção anteroposterior do fêmur na altura do polo superior da patela.

FIGURE 4: Representation of the location of Point 4 (anterolateral femur) and Point 5 (anteromedial femur), where PSP corresponds to the tangent to the upper pole of the patella, perpendicularly to the anatomical axis of the femur and PAP corresponds to the anteroposterior projection of the femur at the level of the upper pole of the patella.

In order to perform the evaluation of the strains under compression, a mechanical device consisting of two cylinders (the upper cylinder for the femur and the lower cylinder for the tibia and fibula) was developed to position the knee in extension. The bone ends were attached to their respective cylinders with J et Clássic $0^{\circledR}$ dental self-polymerizing acrylic cement (polymethylmetacrylate).

Kratos model PA-06-062 AH-350L electrical extensometers were attached to the bone in pre-determined points ( 1 to 9 ) with Loctite's Super-Bonder ${ }^{\circledR}$ cyanoacrylate adhesive and later coated with polyurethane resin (Figure 7).

Once the extensometers were installed, the assembly formed by the anatomical part and the fixing mechanical device was placed in the Kratos 5002 mechanical testing machine (Figure 8). To read the surface microdeformations, each extensometer was connected to the P3500 extensometry bridge (manufactured by Measurement $G$ roup ${ }^{\circledR}$ ) by means of a cable formed by three multifilament wires $0.5 \mathrm{~mm}$ in diameter, according to the manufacturer's specification.

The load was applied in the craniocaudal (compression) direction at a speed of $5 \mathrm{~mm}$ per minute until it reached the value of $686.70 \mathrm{~N}$ (70 kgf); approximately 20 minutes elapsed until the

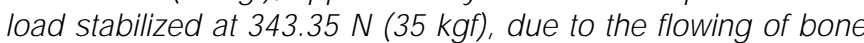
tissue (viscous elastic effect). Once the load stabilized, the reading of the microdeformations was performed in the nine extensometers. The load was removed and the test was repeated after 30 minutes. The results were recorded and the average of the two readings in each extensometer was calculated for both tests.

After the tests were performed with the intact knees, the knee extensor apparatus was removed and a cemented unicompartmental prosthesis was placed in the medial compartment of the right knee, while the anterior and posterior crossed ligaments were preserved (Figure 9). For the leftknee, the cemented total prosthesis was placed,

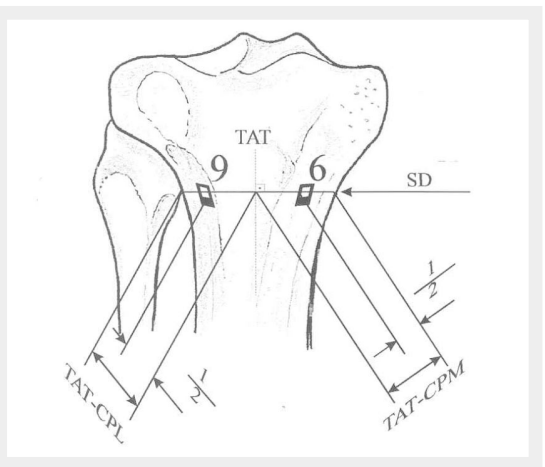

FIGURA 5: Esquema representativo da localização dos pontos 9 (tíbia anterolateral) e ponto 6 (tíbia anteromedial), onde: SD corresponde à linha que tangencia a porção distal da sindesmose tibiofibular proximal, perpendicularmente ao eixo anatômico da tíbia; TAT corresponde tuberosidade anterior da tíbia; CPM corresponde à cortical tibial posteromedial; CPL corresponde à cortical tibial posterolateral. FIGURE 5: Representation of the location of Point 9 (anterolateral tibia) and Point 6 (anteromedial tibia), where SD corresponds to the tangent to the distal portion of the proximal tibiofibular syndesmosis, perpendicularly to the anatomical axis of the tibia; TAT corresponds to the anterior tuberosity of the tibia; CPM corresponds to the posteromedial tibial cortical; and CPL corresponds to the posterolateral tibial cortical.

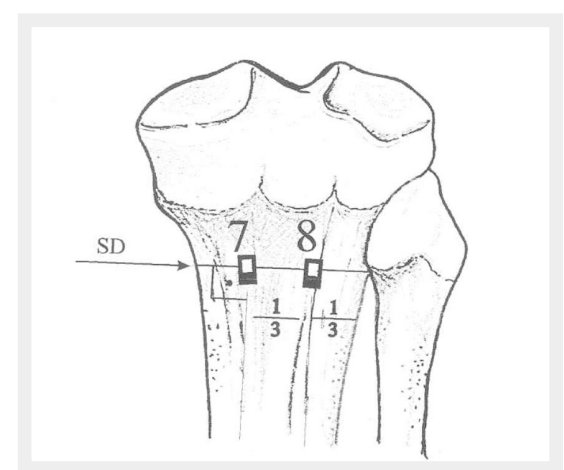

FIGURA 6: Esquema representativo da localização dos pontos 7 (tíbia posteromedial) e ponto 8 (tíbia posterolateral), onde SD corresponde à linha que tangencia a porção distal da sindesmose tibiofibular proximal, perpendicularmente ao eixo anatômico da tíbia.

FIGURE 6: Representation of the location of Point 7 (posteromedial tibia) and Point 8 (posterolateral tibia), where SD corresponds to the tangent to the distal portion of the proximal tibiofibular syndesmosis, perpendicularly to the anatomical axis of the tibia. 
joelho direito prótese unicompartimental cimentada, preservando-se os ligamentos cruzados anterior e posterior, (Figura 9) e, no joelho esquerdo, prótese total cimentada, preservando-se o ligamento cruzado posterior, (Figura 10).

As próteses instaladas foram do modelo SEARCH ${ }^{\circledR}$ fabricado pela Aesculap ${ }^{\circledR}$. Utilizou-se guia intramedular no fêmur e extramedular na tíbia, padronizando-se a opção de 70 para compensação do valgismo entre o eixo mecânico do membro inferior e o eixo anatômico do fêmur, tanto na instalação da artroplastia total como na unicompartimental.

Depois de colocadas as próteses, as peças foram novamente submetidas aos testes de carregamento como os realizados nos joelhos íntegros, calculando-se e anotando-se a média dos dois resultados numéricos de cada extensômetro nos dois testes.

Depois de obtidos os resultados, foi feita a estatística descritiva da média dos valores das microdeformações dos dois ensaios realizados, tanto nos joelhos direitos íntegros e depois

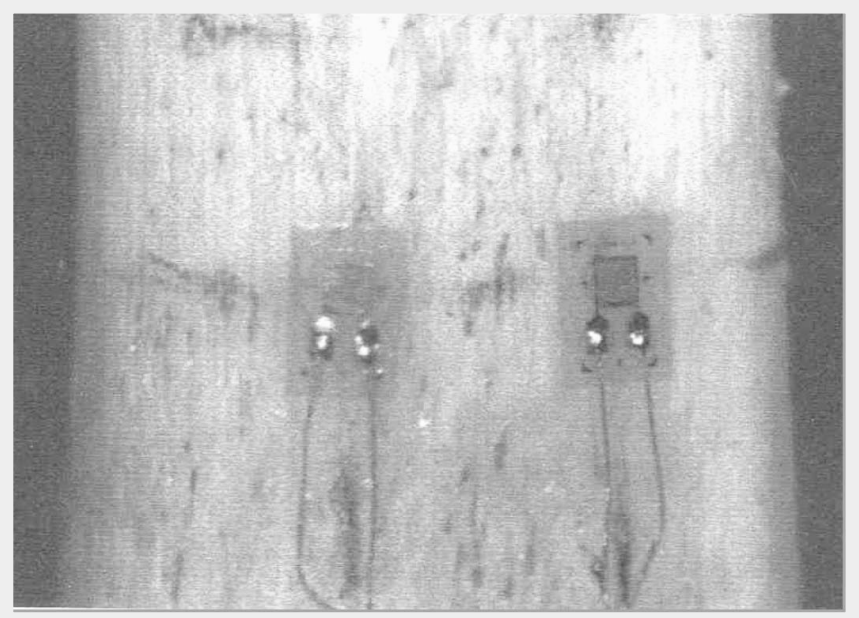

FIGURA 7: Fotografia dos extensômetros elétricos instalados no ponto 4 (fêmur anterolateral) e ponto 5 (fêmur anteromedial) da peça anatômica.

FIGURE 7: Photography of the electrical extensometers installed at Point 4 (anterolateral femur) and Point 5 (anteromedial femur) of the anatomical piece.

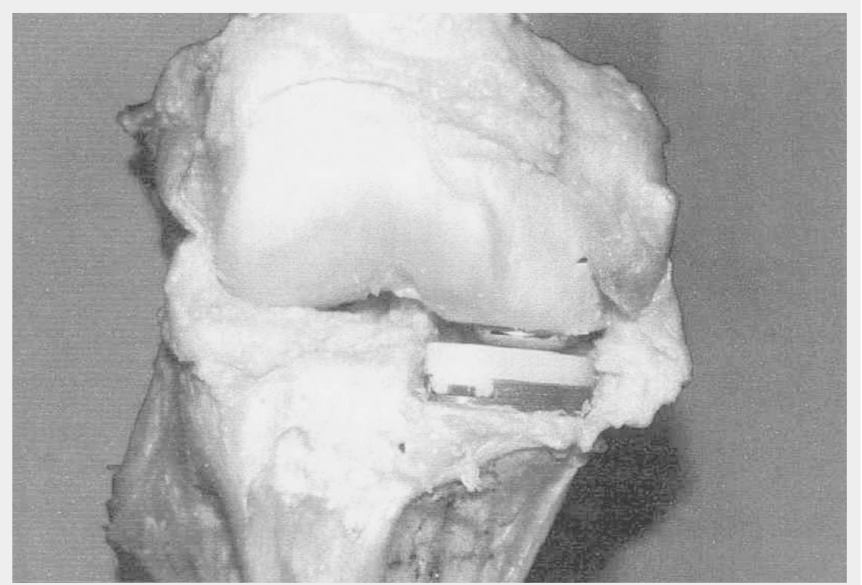

FIGURA 9: Fotografia do joelho direito após a colocação da prótese unic ompartimental.

FIGURE 9: Photography of the right knee after placement of unicompartmental prosthesis. while the posterior crossed ligament was preserved (Figure 10).

The prostheses installed were of the SEARCH ${ }^{\circledR}$ model made by Aesculap ${ }^{\circledR}$. An intramedullary guide was used in the femur, while in the tibia an extramedullary guide was used; the option of 7 degrees to correct valgism between the mechanical shaft of the lower member and the anatomic shaft of the femur was standardized in the installation for both total and unicompartmental arthroplasties.

After placing the prostheses, the pieces were subjected again to loading tests like the ones performed with the intact knees, the average of the two numerical results was calculated and recorded for each extensometer, in both tests.

The results were used in a descriptive statistical study of the mean value of the microdeformations in the two tests performed, both in the intact right knees and after the unicompartmental prosthesis was placed, and after the total prostheses were placed; the mean value (M), the standard deviation (SD) and the stan-

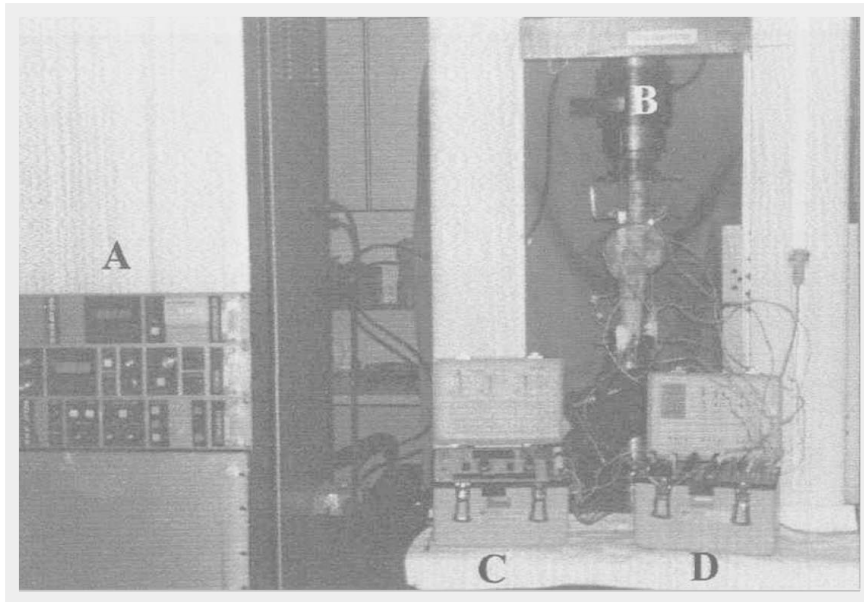

FIGURA 8: Fotografia da máquina de ensaios mecânicos Kratos 5002. A Painel de controle. B: Peça anatômica acoplada ao dispositivo mecânico e adaptada à célula da carga (10tf). C: Ponte de extensometria elétrica P3500. D: Unidade de seleção e balanço SB10.

FIGURE 8: Photography of the Kratos 5002 mechanical testing machine. A: Control panel. B: Anatomical piece coupled to the mechanical device and adapted to the load cell (10 tf). C: Bridge of extensometry Electrical P3500. D: Unit for selection and balance SB 10.

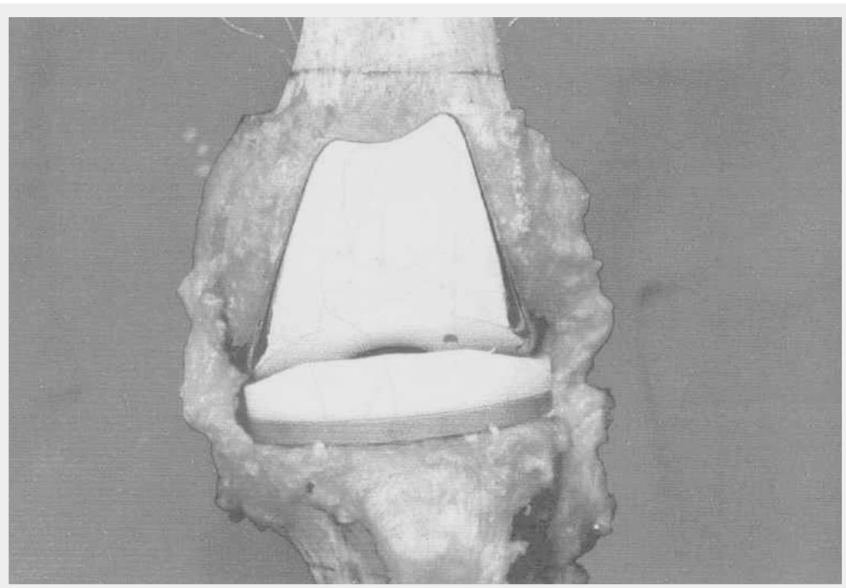

FIGURA 10: Fotografia do joelho esquerdo após a colocação da prótese total FIGURE 10: Photography of the left knee after placement of the total prosthesis. 
da colocação das próteses unicompartimentais, quanto nos joelhos esquerdos íntegros e depois da colocação das próteses totais, calculando-se a média (M), desvio padrão (DP) e o erro padrão da média (EPM) em cada extensômetro.

Comparou-se as microdeformações observadas nos joelhos direitos e esquerdos íntegros com o teste t de Student em cada extensômetro.

Realizou-se a análise comparativa dos valores das microdeformações observadas no joelho direito antes e após a colocação das próteses unicompartimentais, e do joelho esquerdo antes e após a colocação da prótese total pelo teste t pareado, em cada extensômetro.

Adotou-se o nível de significância de $5 \%(\alpha=0,05)$ e os resultados significantes foram evidenciados por asteriscos.

\section{RESULTADOS}

Os resultados das médias das microdeformações superficiais dos joelhos direitos íntegros, por cadáver, em cada extensômetro, encontra-se na Tabela 1.

Os resultados das médias das microdeformações superficiais dos joelhos esquerdos íntegros, por cadáver, em cada extensômetro, encontra-se na Tabela 2.

Os resultados das médias das microdeformações superficiais dos joelhos direitos após a colocação das próteses unicompartimentais, por cadáver, em cada extensômetro, encontra-se na Tabela 3.

Os resultados das médias das microdeformações superficiais dos joelhos esquerdos após a colocação das próteses totais, por cadáver, em cada extensômetro, encontra-se na Tabela 4.

A estatística comparativa entre os valores das microdeformações superficiais observadas nos joelhos direitos e esquerdos íntegros encontra-se na Tabela 5.

A estatística comparativa dos valores das microdeformações superficiais observadas nos joelhos direitos antes e depois da colocação das próteses unicompartimentais encontra-se na Tabela 6 .

A estatística comparativa dos valores das mic rodeformações superficiais observadas nos joelhos esquerdos antes e depois da colocação das próteses totais encontra-se na Tabela 7.

De acordo com a Tabela 5, não existiu diferença estatisticamente significante entre os valores das microdeformações superficiais encontradas nos joelhos direitos e esquerdos íntegros em todos os extensômetros.

De acordo com a Tabela 6, houve um aumento significante das microdeformações em compressão dos valores observados no extensômetro número 1 (fêmur medial), após a colocação da prótese unicompartimental. $(p=0,031)$.

Houve um aumento significante das microdeformações em tração dos valores observados no extensômetro número 3 (fêmur lateral), após a colocação da prótese unicompartimental. $(p=0,015)$.

Houve uma diferença significante das microd eformações em compressão dos valores observados no extensômetro número 5 (fêmur anteromedial), passando de tração para compressão, dard error of the mean (SEM) were calculated for each extensometer.

A comparison among the microdeformations observed in the intact right and left knees in each extensometer was made using Student's t-test.

A comparative analysis of the values of the microdeformations observed in the right knee before and after the placement of the unicompartmental prostheses, as well as the ones observed in the left knee before and after the placement of the total prosthesis by the paired t-test was performed for each extensometer.

A $5 \%$ significance level $(\alpha=0.05)$ was adopted and the significant results were indicated by asterisks.

\section{RESULTS}

The mean values of the surface microdeformations of the intact right knees, per cadaver, in each extensometer, are given in Table 1.

The mean values of the surface microdeformations of the intact left knees, per cadaver, in each extensometer, are given in Table 2.

The mean values of the surface microdeformations of the right knees after the placement of the unicompartmental prostheses, per cadaver, in each extensometer, are given in Table 3.

The mean values of the surface microdeformations of the left knees after the placement of the total prostheses, per cadaver, in each extensometer, are given in Table 4.

A comparative statistical analysis of surface microdeformation values observed in the intact right and left knees is given in Table 5 .

A comparative statistical analysis of surface microdeformation values observed in the right knees before and after the placement of the unicompartmental prostheses is given in Table 6 .

A comparative statistical analysis of surface mic rodeformation values observed in the left knees before and after the placement of the unicompartmental total prostheses is given in Table 7.

According to Table 5, no statistically significant differences were seen between the values of the surface microdeformations found in the intact right and left knees in all extensometers.

According to Table 6, there was a significant increase in the microdeformations in compression of the values observed in extensometer 1 (medial femur), after the placement of the unicompartmental prosthesis $(p=0.031)$.

There was a significant increase in the microdeformations in traction of the values observed in extensometer 3 (lateral femur) after the placement of the unicompartmental prosthesis $(p=0.015)$.

A change from traction to compression produced a significant difference in the microdeformations in compression of the values observed in extensometer 5 (anteromedial femur) after the placement of the unicompartmental prosthesis $(p=0.002)$.

After the placement of the unicompartmental prosthesis, a significant increase in the values of the microdeformations in 
Os valores negativos correspondem a forças de compressão. Negative values correspond to compression forc

Tabela 1 - Resultados das médias das microdeformações superficiais dos joelhos direitos íntegros, por cadáver, em cada extensômetro.

Table 1 - Mean values of the surface microdeformations of the intact right knees, per cadaver, in each extensometer.

\begin{tabular}{|c|c|c|c|c|c|c|c|c|c|}
\hline \multirow[b]{2}{*}{ Extensometer } & \multicolumn{9}{|c|}{ Microdeformations $(\mu \mathrm{m} / \mu \mathrm{m})$} \\
\hline & 1 & 2 & 3 & 4 & 5 & 6 & 7 & 8 & 9 \\
\hline Cadaver 1 & -124 & -169 & 65 & 254 & 146 & -141 & -108 & -62 & -29 \\
\hline Cadaver 2 & -354 & -306 & 36 & 343 & 118 & -455 & -179 & -9 & -134 \\
\hline Cadaver 3 & -250 & -158 & 52 & 175 & -36 & -110 & -83 & -72 & 44 \\
\hline Cadaver 4 & -72 & -108 & -42 & 103 & 45 & -32 & -9 & -115 & -60 \\
\hline Cadaver 5 & -306 & -216 & 66 & 221 & 4 & -147 & -65 & 6 & -33 \\
\hline Cadaver 6 & -45 & -65 & -75 & 43 & 86 & -98 & -82 & -96 & -63 \\
\hline Cadaver 7 & -435 & -389 & 309 & 278 & -94 & -126 & -28 & 46 & 18 \\
\hline Cadaver 8 & -53 & -136 & -49 & 61 & -32 & 7 & -135 & -240 & -124 \\
\hline Cadaver 9 & -37 & -169 & -107 & 116 & 94 & -60 & -59 & -84 & -127 \\
\hline Cadaver 10 & -28 & -156 & -87 & 40 & 62 & -24 & -107 & -125 & -53 \\
\hline$M$ & -170.1 & -186.9 & 16.8 & 163.1 & 39.3 & -118.5 & -85.3 & -75.0 & -56.1 \\
\hline$S D$ & 151.9 & 95.4 & 121.8 & 107.0 & 76.8 & 129.3 & 50.1 & 79.8 & 60.1 \\
\hline SEM & 48.0 & 30.2 & 38.5 & 33.8 & 24.3 & 48.9 & 15.8 & 25.2 & 19.0 \\
\hline \multicolumn{5}{|c|}{$\begin{array}{l}\text { M: média. } \\
\text { DP: desvio padrăo. } \\
\text { EPM: Erro padrão da média. }\end{array}$} & \multicolumn{5}{|c|}{$\begin{array}{l}\text { M: mean. } \\
\text { SD: standard deviation. } \\
\text { SEM: Standard error of the mean. }\end{array}$} \\
\hline \multicolumn{5}{|c|}{ s valores positivos correspo } & & & & & \\
\hline
\end{tabular}

\begin{tabular}{|c|c|c|c|c|c|c|c|c|c|}
\hline \multirow[b]{2}{*}{ Extensometer } & \multicolumn{9}{|c|}{ Microdeformations $(\mu \mathrm{m} / \mu \mathrm{m})$} \\
\hline & 1 & 2 & 3 & 4 & 5 & 6 & 7 & 8 & 9 \\
\hline Cadaver 1 & -131 & -184 & -11 & 129 & 153 & -161 & -153 & -82 & 13 \\
\hline Cadaver 2 & -257 & -367 & 93 & 415 & 114 & -197 & -120 & -22 & 36 \\
\hline Cadaver 3 & -60 & -139 & -76 & 103 & 48 & -58 & 29 & -79 & -180 \\
\hline Cadaver 4 & -98 & -131 & -29 & 92 & 15 & -121 & -49 & -23 & -6 \\
\hline Cadaver 5 & -354 & -239 & 173 & 210 & -84 & -194 & -113 & 21 & 40 \\
\hline Cadaver 6 & -60 & -135 & -62 & 64 & 21 & -40 & -15 & -168 & -162 \\
\hline Cadaver 7 & -291 & -268 & 111 & 140 & -67 & -190 & -23 & -66 & -77 \\
\hline Cada & -130 & -183 & -43 & 110 & 31 & -51 & -43 & -156 & -248 \\
\hline Cadaver 9 & 99 & -123 & -162 & 33 & 110 & -20 & -70 & -168 & -155 \\
\hline Cadaver 10 & -257 & -210 & 118 & 240 & -39 & -170 & -19 & 17 & -3 \\
\hline $\mathrm{M}$ & -153.7 & -197.7 & 11.2 & 153.3 & 30.1 & -119.8 & -57.4 & -72.5 & -74.2 \\
\hline$S D$ & 135.7 & 76.9 & 106.3 & 110.8 & 78.9 & 71.2 & 56.3 & 72.1 & 104.2 \\
\hline SEM & 42.9 & 24.3 & 33.6 & 35.0 & 24.9 & 22.5 & 17.8 & 22.8 & 33.0 \\
\hline $\begin{array}{l}\text { M: médi } \\
\text { DP: des }\end{array}$ & & & & & $\begin{array}{l}\text { SD: } \\
\text { SEM }\end{array}$ & ard & e & & \\
\hline
\end{tabular}

Tabela 2 - Resultados das médias das microdeformações superficiais dos joelhos esquerdos íntegros, por cadáver, em cada extensômetro.

Table 2 - Mean values of the surface microdeformations of the intact left knees, per cadaver, in each extensometer.

\begin{tabular}{|c|c|c|c|c|c|c|c|c|c|}
\hline \multirow[b]{2}{*}{ Extensometer } & \multicolumn{9}{|c|}{ Microdeformations $(\mu \mathrm{m} / \mu \mathrm{m})$} \\
\hline & 1 & 2 & 3 & 4 & 5 & 6 & 7 & 8 & 9 \\
\hline Cadaver 1 & -242 & -172 & 178 & 194 & 44 & -153 & -179 & -33 & 83 \\
\hline Cadaver 2 & -287 & -315 & 59 & 306 & 73 & -347 & -158 & -21 & 119 \\
\hline Cadaver 3 & -268 & -166 & 76 & 140 & -68 & -134 & -137 & -45 & 101 \\
\hline Cadaver 4 & -213 & -135 & 76 & 126 & -45 & -38 & -29 & -173 & -50 \\
\hline Cadaver 5 & -303 & -329 & 85 & 180 & -19 & -139 & -158 & 98 & -168 \\
\hline Cadaver 6 & -151 & -146 & 26 & 179 & 21 & -102 & -86 & -64 & -3 \\
\hline Cadaver 7 & -380 & -302 & 224 & -84 & -127 & -118 & -136 & -56 & 28 \\
\hline Cad & -252 & -201 & 98 & 761 & -70 & -9 & -303 & -173 & 30 \\
\hline Cadaver 9 & -296 & -214 & 81 & 130 & -94 & -195 & -41 & -20 & -28 \\
\hline Cadaver 10 & -270 & -216 & 121 & 160 & -58 & -33 & -145 & -79 & -28 \\
\hline $\mathrm{M}$ & -265.9 & -219.4 & 102.1 & 149.0 & -34.3 & -126.6 & -137.0 & -56.6 & 8.3 \\
\hline SD & 60.1 & 71.4 & 58.4 & 96.5 & 63.3 & 97.4 & 77.1 & 77.9 & 84.5 \\
\hline SEM & 19.0 & 22.6 & 18.5 & 30.5 & 20.0 & 30.8 & 24.4 & 24.6 & 26.7 \\
\hline $\begin{array}{l}\text { M: méd } \\
\text { DP: des }\end{array}$ & & & & & $\begin{array}{l}\text { M: me } \\
\text { SD: st } \\
\text { SEM: }\end{array}$ & ird e & & & \\
\hline
\end{tabular}

\begin{tabular}{|c|c|c|c|c|c|c|c|c|c|}
\hline \multirow[b]{2}{*}{ Extensometer } & \multicolumn{9}{|c|}{ Microdeformations $(\mu \mathrm{m} / \mu \mathrm{m})$} \\
\hline & 1 & 2 & 3 & 4 & 5 & 6 & 7 & 8 & 9 \\
\hline Cadaver 1 & -274 & -217 & 174 & 222 & 25 & -303 & -154 & 32 & 64 \\
\hline Cadaver 2 & -253 & -336 & 95 & 262 & 24 & -184 & -198 & 53 & 178 \\
\hline Cadaver 3 & -83 & -155 & -34 & 64 & -8 & -26 & -185 & -126 & -88 \\
\hline Cadaver 4 & -189 & -170 & 86 & 103 & -79 & -111 & -81 & -8 & 20 \\
\hline Cadaver 5 & -175 & -142 & 38 & 71 & -37 & -158 & -95 & 1 & -46 \\
\hline Cadaver 6 & -52 & -197 & 3 & 63 & 36 & -66 & -115 & -53 & -83 \\
\hline Cadaver 7 & 83 & -85 & -168 & 111 & 104 & 49 & -61 & -68 & -374 \\
\hline Cadaver 8 & -48 & -172 & -48 & 13 & -23 & -38 & -122 & -221 & -174 \\
\hline Cadaver 9 & -156 & -182 & 50 & 47 & -106 & -80 & -67 & -144 & 6 \\
\hline Cadaver 10 & -296 & -211 & 168 & 163 & -106 & -102 & -79 & -1 & 35 \\
\hline $\mathrm{M}$ & -144.1 & -186.4 & 36.3 & 111.6 & -16.9 & -101.6 & -115.5 & -53.4 & -46.2 \\
\hline$S D$ & 119.2 & 64.8 & 103.9 & 80.1 & 67.2 & 97.1 & 48.9 & 86.8 & 150.0 \\
\hline SEM & 37.7 & 20.5 & 32.8 & 25.3. & 21.3 & 30.7 & 15.5 & 27.4 & 47.4 \\
\hline \multicolumn{5}{|c|}{$\begin{array}{l}\text { M: média. } \\
\text { DP: desvio padrão. } \\
\text { EPM: Erro padrăo da média. }\end{array}$} & \multicolumn{5}{|c|}{$\begin{array}{l}\text { M: mean. } \\
\text { SD: standard deviation. } \\
\text { SEM: Standard error of the mean. }\end{array}$} \\
\hline & & & & & & & & & \\
\hline
\end{tabular}

Tabela 3 - Resultados das médias das microdeformações superficiais dos joelhos direitos após colocação das próteses unicompartimentais, por cadáver, em cada extensômetro.

Table 3 - Mean values of the surface microdeformations of the right knees after placement of the unicompartmental prostheses, per cadaver, in each extensometer

após a colocação da prótese unicompartimental. $(p=0,002)$.

Houve um aumento significante das microdeformações em compressão dos valores observados no extensômetro número 7 (tíbia posteromedial), após a colocação da prótese unicompartimental. $(p=0,023)$.

Não existiu diferença estatisticamente significante entre os valores das deformações superficiais encontradas no joelho direito íntegro e após a colocação da prótese unicompartimental nos demais extensômetros.

De acordo com a Tabela 7, houve um aumento significante das microdeformações em compressão dos valores observados no extensômetro número 7 (tíbia posteromedial), após a colocação da prótese total. $(p=0,023)$.

Não existiu diferença estatisticamente significante entre os
Tabela 4 - Resultados das médias das microdeformações superficiais dos joelhos esquerdos após colocação das próteses totais, por cadáver, em cada extensômetro.

Table 4 - Mean values of the surface microdeformations of the left knees after placement of the total prostheses, per cadaver, in each extensometer.

compression was observed in extensometer 7 (posteromedial tibia) $(p=0.023)$.

The other extensometers showed no statistically significant differences in the surface microdeformations found in the intact right knee and after the placement of the unicompartmental prosthesis.

According to Table 7, after the placement of the total prosthesis a significant increase in the values of the microdeformations in compression was observed in extensometer 7 (posteromedial tibia) $(p=0.023)$.

No statistically significant differences were seen in the other extensometers as regards the values of the surface microdeformations found in the intact left knee and after the placement of the total prosthesis. 


\begin{tabular}{|c|c|c|c|}
\hline Extensometer & $\begin{array}{c}\text { Means of the differences } \\
\text { (Microdeformations } \mu \mathrm{m} / \mu \mathrm{m} \text { ) }\end{array}$ & $T$ & $p$ \\
\hline 1 & -16.35 & -0.254 & 0.803 \\
\hline 2 & 10.85 & 0.280 & 0.783 \\
\hline 3 & 5.65 & 0.111 & 0.913 \\
\hline 4 & 9.85 & 0.202 & 0.842 \\
\hline 5 & 9.15 & 0.263 & 0.796 \\
\hline 6 & 1.30 & 0.028 & 0.978 \\
\hline 7 & -27.85 & -1.168 & 0.258 \\
\hline 8 & -2.50 & -0.073 & 0.942 \\
\hline 9 & 18.10 & 0.476 & 0.640 \\
\hline
\end{tabular}

Student's t-test

Tabela 5 - Estatística comparativa entre resultados das médias das microdeformações superficiais dos joelhos direitos e esquerdos antes da colocação das próteses. (joelhos íntegros)

Table 5 - Comparative statistical analysis of mean values of the surface microdeformations of the right and left knees before the placement of the prostheses (intact knees).

\begin{tabular}{|c|c|c|c|}
\hline Extensometer & $\begin{array}{c}\text { Means of the differences } \\
\text { (Microdeformations } \mu \mathrm{m} / \mu \mathrm{m} \text { ) }\end{array}$ & $\mathrm{T}$ & $\mathrm{p}$ \\
\hline \hline 1 & 95.80 & 2.556 & $0.031^{*}$ \\
\hline 2 & 32.55 & 1.879 & 0.093 \\
\hline 3 & -85.30 & -3.015 & $0.015^{*}$ \\
\hline 4 & 14.10 & 0.315 & 0.760 \\
\hline 5 & 73.60 & 4.465 & $0.002^{*}$ \\
\hline 6 & 8.15 & 0.444 & 0.668 \\
\hline 8 & 51.70 & 2.731 & $0.023^{*}$ \\
\hline 9 & -18.45 & -0.976 & 0.354 \\
\hline
\end{tabular}

Paired t-test

Tabela 6 - Estatística comparativa entre resultados das médias das microdeformações superficiais dos joelhos direitos antes e depois da colocação das próteses unicompartimentais.

Table 6 - Comparative statistical analysis of mean values of the surface microdeformations of the right knees before and after the placement of the unicompartmental prostheses. valores das microdeformações superficiais encontradas no joelho esquerdo íntegro e após a colocação da prótese total nos demais extensômetros.

\section{DISCUSSÃO}

As alterações nos fluxos de tensão provocadas pelo material de implante, promovendo um remodelamento na disposição das trabéculas ósseas, são reconhecidas de longa data ${ }^{(1,11,24)}$. Porém, em relação

\begin{tabular}{|c|c|c|c|}
\hline Extensometer & $\begin{array}{c}\text { Means of the differences } \\
\text { (Microdeformations } \mu \mathrm{m} / \mu \mathrm{m} \text { ) }\end{array}$ & $\mathrm{T}$ & $\mathrm{p}$ \\
\hline 1 & -9.65 & -0.175 & 0.865 \\
\hline 2 & -11.3 & -0.465 & 0.653 \\
\hline 3 & -25.15 & -0.547 & 0.597 \\
\hline 4 & 41.70 & 1.734 & 0.117 \\
\hline 5 & 47.10 & 1.419 & 0.189 \\
\hline 6 & -18.15 & -0.590 & 0.570 \\
\hline 7 & 58.10 & 2.728 & $0.023^{\star}$ \\
\hline 9 & -19.15 & -0.957 & 0.364 \\
\hline
\end{tabular}

Paired t-test

Tabela 7 - Estatística comparativa entre resultados das médias das microdeformações superficiais dos joelhos esquerdos antes e depois da colocação das próteses totais.

Table 7 - Comparative statistical analysis of mean values of surface microdeformations of the left knees before and after the placement of the total prostheses. às próteses de joelho, os trabalhos específicos são mais raros: Bourne e Finlay ${ }^{(2)}$ e Whiteside e Pafford ${ }^{(20)}$ realizaram estudo experimental para avaliação da distribuição de carga através de extensômetros, mas restrito à tíbia; Hvid et al. ${ }^{(6)}$ avaliaram a reabsorção óssea através de densitometria e Tissakht et al. ${ }^{(28)}$, Van Lenthe et al. ${ }^{(29)}$ e Lewis et al. ${ }^{(15)}$ fizeram o mesmo em modelos por elementos finitos em computador.

Casos de fratura de fadiga no fêmur proximal após artroplastia total descritos por Kumm et al. ${ }^{(10)}$ e Rawes et al. ${ }^{(21)}$ e de fratura de fadiga na tíbia após artroplastia unicompartimental descrito por Rossetti et al. ${ }^{(23)}$, também indicam a existência de alterações nos fluxos de tensão após esses procedimentos.

Os fluxos de tensão de determinada estrutura, quando submetida a carga, estão diretamente relacionados com a deformação que ocorre na estrutura, segundo a seguinte fórmula:

\section{$\boldsymbol{\sigma}=\boldsymbol{\varepsilon} . \boldsymbol{E}$}

Nesta fórmula, $\boldsymbol{\sigma}$ corresponde à tensão normal, sendo que os valores positivos referem-se à tração e os valores negativos à compressão, com valores expressos em N/m²; $\boldsymbol{E}$ corresponde ao módulo de elasticidade ou coeficiente de Young, sendo uma característica própria do material, com seus valores expressos também em $\mathrm{N} / \mathrm{m}^{2} ; \boldsymbol{\varepsilon}$ corresponde à deformação superficial com valores expressos em $\mathrm{m} / \mathrm{m}$.

O osso por não ser uma estrutura homogênea, apresenta

\section{DISCUSSION}

The changes in strain flows caused by the implant material promote a remodeling in the arrangement of the bone trabeculae and are long known ${ }^{(1,11,24)}$ However, specific trials regarding knee prostheses are quite rare. The trials performed by Bourne and Finlay ${ }^{(2)}$ and Whiteside and Pafford ${ }^{(20)}$ to evaluate the load distribution using extensometers were limited to the tibia; Hvid et al ${ }^{(6)}$ evaluated the bone resorption by densitometry, and Tissakht et al ${ }^{(28)}$, Van Lenthe et $\mathrm{al}^{(29)}$ and Lewis et al ${ }^{(15)} \mathrm{did}$ the same in models using a computerized analysis of finite elements.

Cases of fatigue fracture in the proximal femur after total arthroplasty described by Kumm et $\mathrm{al}^{(10)}$ and Rawes et $\mathrm{al}^{(21)}$ and of tibial fatigue fracture after unicompartmental arthroplasty described by Rossetti et $a^{(23)}$ also indicate the existence of changes in the strain flows after such procedures.

In a given structure subjected to load, the strain flows relate directly to the deformation occurring in the structure, according to the formula below

\section{$\sigma=\varepsilon . E$}

where $\boldsymbol{\sigma}$ corresponds to normal strain and the positive values refer to traction, while the negative values correspond to compression, all the values being expressed in N/m²; $\boldsymbol{E}$ corresponds to the elasticity module or Young coefficient and is a characteristic of the material, its values also being expressed in $\mathrm{N} / \mathrm{m}^{2}$; $\boldsymbol{\varepsilon}$ corresponds to surface deformation, with values expressed in $\mathrm{m} / \mathrm{m}$.

Since it is not a homogeneous structure, the bone is very prone to change according to the region studied, and such changes reflect in the values of the elasticity module $(\boldsymbol{E})$. We may consider in our study that there were no changes in the values of the bone elasticity module because our comparisons referred to 
grande variabilidade, conforme a região estudada, nos valores do módulo de elasticidade $(\boldsymbol{E})$. No nosso estudo, podemos considerar que não houve variação nos valores do módulo de elasticidade do osso, por estarmos fazendo comparações com o joelho íntegro e após a colocação das próteses sempre no mesmo ponto do osso. Portanto, as microdeformações superficiais ( $\boldsymbol{\varepsilon}$ ) observadas em determinado ponto do osso, quando da aplicação da carga, correspondem diretamente ao valor da tensão superficial $(\boldsymbol{\sigma})$ daquele ponto.

Para o nosso estudo não fizemos restrições à idade dos cadáveres porque essa comparação não foi feita entre os valores absolutos observados nos joelhos com os dois tipos de próteses, mas entre as diferenças dos valores observados com 0 joelho íntegro e após a colocação de cada tipo de prótese.

A criação do dispositivo mecânico teve como intuito promover a adaptação adequada das peças anatômicas à máquina de ensaios mecânicos. A fixação das peças anatômicas ao dispositivo com cimento acrílico, promoveu uma melhor congruência entre as peças e o dispositivo mecânico, homogeneizando as tensões na região da fixação, diminuindo a interferência da fixação nos resultados.

A retirada do aparelho extensor do joelho para a realização dos testes de carga teve o objetivo de facilitar a colocação das próteses nas peças anatômicas sem danificar os extensômetros. Esse procedimento pode ser realizado, sem comprometimento dos resultados, porque a extensão completa do joelho é mantida pela tensão da cápsula posterior e dos ligamentos, sem qualquer participação do aparelho extensor ${ }^{(2)}$.

Procuramos localizar os extensômetros em todas as faces do terço distal do fêmur e proximal da tíbia. Escolhemos, também, pontos próximos à inserção da cápsula articular do joelho, pois quanto mais longe dos pontos de fixação da peça, mais susceptível a deformações estará a estrutura.

Como não comparamos os valores absolutos observados após a colocação das próteses totais e unicompartimentais em cada par de joelho, mas comparamos as diferenças entre os valores observados com o joelho íntegro e após a colocação das próteses totais e unicompartimentais, pequenas diferenças de localização dos pontos estudados não interferiram no resultado.

Em relação à prótese total, optamos pelo tipo que preserva o ligamento cruzado posterior por ser a mais freqüentemente utilizada e por alterar menos o estoque ósseo da porção distal do fêmur, diferenciando-se menos da prótese unicompartimental do que a prótese total que substitui o ligamento cruzado posterior. Com a escolha deste tipo de prótese total introduzimos menos variáveis para a nossa comparação.

A colocação da prótese unicompartimental no compartimento medial se deu porque esse é o compartimento mais freqüentemente comprometido na artrose do joelho.

A opção pelo guia intramedular para a realização dos cortes femorais e colocação do componente femoral nos dois tipos de próteses, se deu por não podermos utilizar a cabeça femoral como parâmetro de orientação do guia extramedular. Para a confecção dos cortes tibiais, utilizamos o guia extramedular e o eixo da tíbia foi utilizado como parâmetro de orientação desse guia. the intact knee and after the placement of the prostheses always in the same site of the bone. Therefore, the surface microdeformations $(\varepsilon)$ observed in a given site of the bone when a load was applied correspond directly to the value of the surface strain $(\boldsymbol{\sigma})$ of that site.

In our study we did not take into account the age of the cadavers because the comparison was not between the absolute values observed in the knees with the two types of prostheses, but between the differences of the values observed with the intact knees and after the placement of each type of prosthesis.

The purpose of creating the mechanical device was to promote the proper adaptation of the anatomical pieces to the mechanical testing machine. Attaching the anatomical pieces to the device using acrylic cement improved the congruence between the pieces and the mechanical device, since the strains in the region of attachment were homogenized and the attachment interfered less with the results.

The purpose of removing the knee extensor apparatus to perform the loading test was to facilitate the placement of the prostheses in the anatomical pieces without damaging the extensometers. This procedure may be performed with no compromise to the results because the knee is kept completely extended by straining the posterior capsule and the ligaments, with no involvement of the extending apparatus ${ }^{(2)}$.

We tried to locate the extensometers in every side of the distal third of the femur and of the proximal third of the tibia. Also, we chose points that were close to the insertion of the knee joint capsule because, the farther the fixing points of the piece are located, the more susceptible to deformations the structure will be.

Since we did not compare the absolute values observed after the placement of the total and unicompartmental prostheses in each pair of knees, but the differences between the values observed with the intact knee and after the placement of the total and unicompartmental prostheses, small differences of location of the points studied did not interfere with the results.

As regards the total prosthesis, we chose the type that preserves the posterior crossed ligament because it is the most frequently used prosthesis and because it changes less the bone depot of the femoral distal point, being less differentiated from the unicompartmental prosthesis than the total prosthesis, that replaces the posterior crossed ligament. By choosing this type of total prosthesis, we have introduced fewer variables in our comparison.

The placement of the unicompartmental prosthesis in the medial compartment was performed because this is the most frequently impaired compartment in knee arthrosis.

The option to use the intramedullary guide to perform the femoral cuts and to place the femoral component in the two types of prostheses was based on the fact that we could not use the femoral head as a guiding parameter of the extramedullary guide. To make the tibial cuts we used the extramedullary guide, while the tibial axis was used as a guiding parameter for that guide.

In this study we used cemented prostheses because they are of the most frequently used type and initially promote a more stable way of fixing the prostheses than without using cement $(14,27)$. With this, the trial's results are more reliable. 
Utilizamos, nesse estudo, próteses cimentadas por ser o tipo mais freqüentemente empregada e por promover uma fixação inicial mais estável que as próteses sem cimento ${ }^{(14,27)}$. Esta fixação inicial mais estável torna os resultados do experimento mais confiáveis.

Tanto nas próteses unicompartimentais como nas totais, padronizamos a utilização do ângulo 70 para a correção do valgismo entre o eixo mecânico do membro inferior e o eixo anatômico do fêmur, por ser o ângulo normal|(7).

Quanto ao ensaio de compressão optamos por realizar as leituras das deformações com a carga estabilizada em 343,35 $\mathrm{N}$ (35 kgf) o que corresponderia ao apoio bipodálico de um indivíduo de $70 \mathrm{~kg}$.

A carga foi aplicada em extensão porque, de acordo com Hilding et al. ${ }^{(5)}$, nessa situação, simula-se as forças que atravessam o joelho durante a marcha.

Em relação à comparação dos valores observados nos joeIhos direitos e esquerdos íntegros (Tabela 5), o estudo estatístico revelou não haver diferenças entre os dois grupos. Portanto, o fato de todas as próteses unicompartimentais serem colocadas nos joelhos direitos e todas as próteses totais serem colocadas nos joelhos esquerdos não interferiu no resultado.

Em relação ao fêmur distal, a grande variação das deformações superficiais no ponto 5, fêmur anteromedial, com valores ora de tração ora de compressão e com valores próximos de zero tanto no joelho íntegro, após a colocação dos dois tipos de próteses, sugere que esse ponto estaria localizado próximo a uma zona neutra. Neste local, o osso não estaria sofrendo forças importantes de tração ou compressão. Talvez este achado esteja relacionado com a reabsorção óssea observada por alguns autores na face anterior do fêmur após a artroplastia total do joelho ${ }^{(20,28,29)}$.

Ainda quanto ao fêmur distal, a colocação da prótese total não causou alterações estatisticamente significantes nas microdeformações superficiais quando comparado com o joelho íntegro. Este fato pode ser explicado porque, na prótese total, os dois côndilos femorais são substituídos, o que manteria o padrão da distribuição das deformações superficiais. (Figura 11).

Apesar de os nossos resultados não apresentarem diferenças estatisticamente significantes entre os joelhos íntegros e após a colocação das próteses totais, houve uma diminuição das médias, como nos achados de Tissakht et al. ${ }^{(28)}$ em estudo realizado em computador.

Q uanto à prótese unicompartimental, ela alterou o padrão das deformações superficiais no fêmur distal. 0 componente femoral desta prótese, por ser mais rígido e por diminuir a área de contato entre o fêmur e a tíbia, confere maior concentrações de tensões a esse compartimento. No compartimento lateral, as cargas tendem a se dissipar pela presença do menisco lateral, que aumenta a área de contato entre o fêmur e a tíbia e junto com a maior quantidade de osso esponjoso conferem maior viscoelasticidade e acomodação das estruturas. Isso leva a resultante das forças nos côndilos femorais a se deslocar medialmente, aumentando o momento adutor do joelho e gerando uma maior microdeformação superficial em compressão na cortical medial, ponto 1 , e em tração na cortical lateral, ponto 3. (Figura 11).
Both for unicompartmental prostheses and total prostheses, we standardized the use of the 7-degree angle for the correction of valgism between the lower limb mechanical axis and the femoral anatomical shaft, since it is the normal angle (7).

As to the compression test, we decided to make the readings of the deformations with the load stabilized at $343.35 \mathrm{~N} \mathrm{(35}$ $\mathrm{kgf}$ ), which would correspond to the bipodal support of an individual weighing $70 \mathrm{~kg}$.

The load was applied in extension because, according to Hilding et $\mathrm{al}^{(5)}$, in this situation it is possible to simulate the forces that cross the knee during the march.

As to the comparison of the values observed in the intact right and left knees (Table 5), the statistical study showed no differences between the two groups. Therefore, the fact that all unicompartmental prostheses were placed in the right knees and all the total prostheses were placed in the left knees did not interfere with the results.

As to the distal femur, the large variation in the surface deformations at Point 5, anteromedial femur, with in-traction or incompression values and with values close to zero in the intact knee, after the placement of the two types of prostheses, suggests that this point would be located near a neutral zone. There, the bone would not be subject to important traction or compression forces. This finding may be related to the bone resorption observed by some authors in the femoral anterior side after a total knee arthroplasty ${ }^{(20,28,29)}$.

Also as regards the distal femur, the placement of the total prosthesis did not cause statistically significant changes in the surface microdeformations as compared with the intact knee. This might be explained by the fact that in the total prosthesis the two femoral condyles are replaced, which would maintain the distribution pattern of the surface deformations (Figure 11).

Although our results present no statistically significant differences between the intact knees and after the placement of the total prostheses, the mean values decreased, as found by Tissakht et al ${ }^{(28)}$ in a computerized study.

As to the unicompartmental prosthesis, it has changed the pattern of the surface deformations in the distal femur. Since the femoral component of this prosthesis is more rigid and decreases the contact area between the femur and the tibia, it provides larger concentrations of strains to this compartment. In the lateral compartment, the loads tend to dissipate due to the presence of the lateral meniscus, which increases the contact area between the femur and the tibia and, together with the higher amount of spongy bone, provide the structures with a higher viscoelasticity and better accommodation. This leads the resultant of the forces in the femoral condyles do be medially shifted, thus increasing the aductor moment of the knee and generating a larger surface microdeformation in compression in the medial cortical (Point 1) and in traction in the lateral cortical (Point 3) (Figure 11).

This is a particularly important finding because the type of unicompartmental prosthesis utilized in our study will correct the difference between the anatomic al and mechanic al axes of the femur. The unicompartmental prostheses where this difference is not offset, keeping a varum knee as advocated by Brou- 
Esse achado é particularmente importante, porque o tipo de prótese unicompartimental utilizado no nosso experimento corrige a diferença entre o eixo anatômico e mecânico do fêmur. Aquelas próteses unicompartimentais, em que não se compensa essa diferença, mantendo-se o varismo do joelho como preconizam Broughton et al. ${ }^{(3)}$, Romagnoli(22), Marmour ${ }^{(16)}$ gerariam tensões ainda maiores no fêmur distal.

A tíbia proximal, por ter uma anatomia e uma arquitetura das trabéculas ósseas distinta do fêmur distal, apresentou uma resposta diferente após a colocação das próteses. Em ambos os tipos de próteses houve um aumento significativo da compressão apenas na cortical posteromedial. Esse fato pode ser explicado porque a maior parte da carga da tíbia proximal passa pela porção medial segundo Burnstein ${ }^{(4)}$ e a substituição de todo o planalto tibial ou apenas do côndilo medial provocou alterações semelhantes nas tensões superficiais na tíbia proximal.

A esclerose óssea sob o componente tibial das próteses unicompartimentais observadas por Romagnoli(22) corroboram com esses achados. Outra evidência são as falhas das artroplastias unicompartimentais por afundamento do componente tibial da prótese $^{(8,12,17,23)}$.

As vantagens teóricas da prótese unicompartimental, como menor agressão cirúrgica, manutenção dos ligamentos cruzados e restabelecimento da tensão dos ligamentos colaterais, preservando, portanto, a biomecânica normal do joelho, não são traduzidas em resultados tão animadores na prática clínica ${ }^{(19)}$. Esses índices de resultados satisfatórios inferiores aos da artroplastia total Martucci et al..$^{(18)}$ e Scott(25) poderiam ser explicados pelo aumento das tensões no fêmur distal. 0 aumento das tensões no fêmur distal fazem com que a resultante das forças que passam pelo joelho se desloquem medialmente, concentrando ainda mais essas forças no compartimento femorotibial medial (Figura 11). Como o componente tibial da prótese unicompartimental apoia-se nas corticais medial, posteromedial e anteromedial, enquanto que a sua borda lateral apoia-se em osso esponjoso, o aumento das tensões no compartimento medial e a falta de apoio da borda lateral da prótese poderiam ocasionar 0 afundamento do seu componente tibial, comprometendo os seus resultados. 0 mesmo não ocorre com a prótese total, porque além de gerar menos tensões no terço distal do fêmur, ela apoia o seu componente tibial em todo o perímetro da cortical tibial e, possui também, a haste intramedular agindo com transmissor de $\operatorname{carga}^{(30)}$.

Os melhores resultados observados nas artroplastias unicompartimentais realizadas no compartimento lateral em relação ao medial por Insall e Walker $^{(9)}$, Laskin ${ }^{(13)}$ e Insall e Agli- ghton et al ${ }^{(3)}$, Romagnoli(22) and Marmour ${ }^{(16)}$ would generate even greater strains in the distal femur.

Because the anatomy and architecture of the bone trabeculae in the proximal tibia are different from the ones in the distal femur, the proximal tibia presented a different response after the placement of the prostheses. In both types of prostheses a signific ant increase of compression appeared in the posteromedial cortical only. This may be explained by the fact that the main portion of the load of the proximal tibia crosses the medial portion, according to Burnstein ${ }^{(4)}$ and the replacement of the whole tibial plateau or of the medial condylus only, has caused similar changes in the surface strain of the proximal tibia.

The bone sclerosis under the tibial component of the unicompartmental prostheses that were observed by Romagnoli (22) corroborates these findings. Further evidence is given by the defects of the unicompartmental arthroplasties by subsidence of the tibial component of the prosthesis ${ }^{(8,12,17,23)}$.

The theoretical benefits of unicompartmental prosthesis, such as less surgical aggression, maintenance of crossed ligaments and recovery of the strain in the collateral ligaments, thus preserving the normal biomechanics of the knee, do not translate into results that are encouraging in the clinical practice ${ }^{(19)}$. The indices of satisfactory results that are inferior to those in total arthroplasty (see Martucci et al ${ }^{(18)}$ and $S \operatorname{Sot} t^{(25)}$ ) might be explained by the increase in the strains in the distal femur. The increase of strains in the distal femur makes the resultant of the forces crossing the knee to be medially shifted, concentrating such forces even more in the medial femorotibial compartment (Figure 11). Since the tibial component of the unicompartmental prosthesis is supported by the medial, posteromedial and anteromedial corticals, while its lateral border is supported by spongy bone, the strain increase in the medial compartment, plus the absence of support for the side border of the prosthesis could cause the subsidence of its tibial component, impairing its results. This does not occur with the total prosthesis because, besides generating fewer strains in the distal third of the femur, this type of prosthesis places its tibial component on the whole perimeter of the tibial cortical, besides the fact that the intramedullary stem acts as a load transmitter ${ }^{(30)}$.

The better results observed in unicompartmental arthroplasties performed in the lateral compartment as compared to the medial compartment by Insall and Walker $^{(9)}$, Laskin ${ }^{(13)}$ and Insall and Agliett( ${ }^{(8)}$ suggest that these prostheses, when placed in sites with less force transmission, will present a better evolution.

Our study suggests that the new designs of unicompartmental prostheses should be developed taking into account this 
ettl ${ }^{(8)}$, sugerem que essas próteses, quando colocadas em locais onde existe menor transmissão de força, apresentam meIhor evolução.

Nosso trabalho sugere que os novos desenhos de próteses unicompartimentais deveriam ser desenvolvid os levando-se em consideração esse aumento das tensões no compartimento medial do joelho e abre perspectiva de novos estudos para avaliar as alterações das deformações superficiais por próteses totais com substituição do ligamento cruzado posterior ou pela presença das hastes intramedulares femorais e tibiais.

\section{CONCLUSÕES}

1. A prótese total do joelho mantém o padrão de distribuição das cargas no terço distal do fêmur.

2. A prótese unicompartimental, quando colocada no compartimento medial do joelho, aumenta as tensões de compressão na cortical medial do fêmur distal e as tensões de tração na cortical lateral do fêmur distal.

3. Os componentes tibiais (parcial medial e total) aumentam, da mesma forma, as tensões de compressão na cortical póstero-medial da tíbia.

\section{REFERÊNCIAS BIBLIOGRÁFICAS}

1. Bobyn J D, Cameron MB, Abdulla D, Pillar RM, Weatherly GC. Biologic fixation and bone modeling with an incontrained canine total knee prosthesis. Clin Orthop 166:301-312, 1982.

2. Bourne RB, Finlay JB. The influence of tibial component intramedullary stems and implant-cortex contact on the strain distribution of the proximal tibial following total knee arthroplasty. Clin Orthop 208:95-99, 1986.

3. Broughton NS, Newman JH, Baily RAJ. Unicompartmental replacement and high tibial osteotomy for osteoarthrits of the knee. J. Bone J oint Surg Br 68:447452,1986

4. Burnstein $\mathrm{AH}$. Biomechanics of the knee. In: Insall, J N ed. Surgery of the knee. New York: Churchill Livingstone, 1984. p.21-39.

5. Hilding MB, Lanshammar $\mathrm{H}$, Ryd L. A relationship between dynamic and static assessments of knee joint load. Acta Orthop Scand 66:317-320, 1995.

6. Hvid I, Bentzen SM, J orgensen J. Remodeling of the tibial plateau after knee replacement. Acta Orthop Scand 59:567-573, 1988.

7. Insall J N. Surgical techniques and instrumentation in total knee arthroplasty. In: Insall J N, Windsor RE, Scott WN, Kelly MA, Aglietti P, eds. Surgery of the knee. $2^{\text {nd }}$ ed. New York: Churchill Livingstone, 1993. p.739-803.

8. Insall J N, Aglietti PA. Five to seven year follow-up of unicondilar arthroplasty. J Bone J oint Surg Am 62:329-337, 1980. 1976.

9. Insall J N, Walker P. Unicondilar knee replacement. Clin Orthop 120:83-85,

10. Kumm DA, Rack C, Rütt J. Subtrochanteric stress fracture of the femur following total knee arthroplasty. J Arthroplasty 12:580-583, 1997.

11. Lanyon LE, Hampson WGJ, Goodship AE, Shah J S. Bone deformation recorded in vivo from strain gauges attached to the human tibial shaft. Acta Orthop Scand 46:256-268, 1975.

12. Larsson SE, Ahlgren 0 . Reconstruction with endoprosthesis in gonarthrosis. Clin Orthop 145:126-135, 1979.

13. Laskin RS. Unicompartmental tibiofemoral resurfacing arthroplasty. J . Bone J oint Surg Am 60:182-185, 1978.

14. Lee RW, Volz RG, Sheridan DC. The role of fixation and bone quality on the mechanical stability of the tibial components. Clin Orthop 273:177-183, 1991.

15. Lewis J L, Askew MJ , J aycox DP. A comparative evaluation of tibial component designs of total knee prostheses. J Bone J oint Surg Am 64:129-135, 1982.

16. Marmour L.Unicompartmental arthroplasty. In: Fu FH, Harner CD, Vince KG, eds. Knee Surgery. Baltimore: Williams \& Wilkins, 1994. p. 1181-1202. increase in the strains in the medial compartment of the knee, and opens the perspective for new studies to evaluate the changes in surface deformations by total prostheses with replacement of the posterior crossed ligament or by the presence of the femoral and tibial intramedullary stems.

\section{CONCLUSIONS}

1. The total prosthesis of the knee maintains the distribution pattern of the loads in the distal third portion of the femur.

2. When placed in the medial compartment of the knee, the unicompartmental prosthesis increases the compression strains in the medial cortical of the distal femur and the traction strains in the lateral cortical of the distal femur.

3. Likewise, the tibial components (partial medial and total) increase the compression strains in the tibial posteromedial cortical.

17. Marmour L. Unicompartmental knee arthroplasty. Ten-to-13 year follow up study.Clin Orthop 226:14-20, 1988

18. Martucci E, Verni E, Del Prete G, Stulberg SD. L'artroprotesi di ginocchio CKS: elementi di biomeccanica e risultati di 42 casi. Chir Organi Mov 81: 247 256, 1996.

19. Mccallum J D, Scott RD. Duplication of medial erosion in unicompartmental knee arthroplasties. J Bone J oint Surg Br 77:726-728, 1995.

20. Mintzer CM, Robertson DD, Rackemann S, Ewald FC, Scott RD, Spector, $M$. Bone loss in the distal anterior femur after total knee arthroplasty. Clin Orthop 260:135-143, 1990

21. Rawes ML, Patsalis T, Gregg PJ. Subcapital stress fractures of the hip complicating total knee replacement. Injury 26:421-423, 1995.

22. Romagnoli $\mathrm{S}$. The unicompartmental knee prosthesis and the rotatory gonarthrosis kinematic. In: Insall I N; Scott WM; Scuderi GR, eds. Currenti concepts in primary and revision total knee arthroplasty. Philadelphia, Lippincott-Raven, 1996. p. 69-83

23. Rossetti AC, Amatuzzi MM, Albuquerque RFM, Pécora J R, Olivi R. Complicações de artroplastia unicompartimental do joelho observadas em 48 joelhos operados. Anais. In: CONGRESSO BRASILEIRO DE ORTOPEDIA E TRAUMATOLOGIA, 31., Goiânia, 1998. p. 58.

24. Rubin CT, Lanyon LE. Regulation of bone formation by applied dynamic loads. J Bone J oint Surg Am 66:397-402, 1984

25. Scott RD. Unicompartmental replacement: another look. In: CURRENT CONCEPTS IN J OINT REPLACEMENT, 15, Orlando, 1998. p.121.

26. Scuderi GR, ed. Current concepts in primary and revision total knee arthroplasty. Philadelphia: Lippincott-Raven, 1996. p.69-83.

27. Stern SH, Wills RD, Gilbert J L. The effect of tibial stem design on component micromotion in knee arthroplasty. Clin Orthop 345:44-52, 1997.

28. Tissakht M, Ahmed AM, Chan KC. Calculated stress-shielding in the distal femur after total knee replacement corresponds to the reported location of bone loss. J Orthop Res 14:778-785, 1996.

29. Van Lenthe GH, Malefijt MCW, Huiskes R. Stress shielding after total knee replacement may cause bone resorption in the distal femur. J Bone J oint Surg Br 79:117-122, 1997

30. Whiteside LA, Pafford J . Load transfer characteristics of a noncimented total knee arthroplasty. Clin Orthop 239:168-177, 1989. 